\title{
Role of Indian Women in Conservation of Biodiversity
}

\author{
Ishan Saini $^{1^{*}}$, Prashant Kaushik ${ }^{2}$ and Babu Lal Saini ${ }^{1}$ \\ ${ }^{1}$ Department of Botany, Kurukshetra University Kurukshetra, Kurukshetra 136119, India \\ ${ }^{2}$ Instituto de Conservación y Mejora de la Agrodiversidad Valenciana, Universitat Politècnica \\ de València, 46022 Valencia, Spain \\ *Corresponding author
}

\section{A B S T R A C T}

India is a country of rich cultural heritage. In India, there are several festivals which convey some message for the importance of nature and natural objects. Indian women who are considered as custodian of household activities as well as play a significant role in celebrating the various festivals. Most of these activities are devoted to highlighting the importance of celestial bodies and wildlife conservation. Indian woman place Ocimum

\section{Keywords}

Indian women, Biodiversity, Ficus religiosa, Bishnois, Sacrifice

Article Info

Accepted:

04 March 2019

Available Online:

10 April 2019 sanctum (Tulsi) plant in the courtyard of their house and daily water and worship it. This is a symbolic representation of caring and devotion towards plants. Not only this, Indian woman tie a cotton thread on the trunk of Ficus religiosa (Peepal) tree and worship it. This practice highlight the importance of $F$. religiosa as this tree not only releases plenty of Oxygen but also supports a number of birds and other insects by way of providing food and shelter. Besides it, this tree has a thick canopy and provides shade and a place of rest under it to numbers of other wildlife creatures. When an Indian woman prepares a meal for her family she, first of all, cooks one or two chapattis (bread) for stray dogs and cows showing her love to biodiversity. Indian woman does offer grains to birds and flour to ants daily. In India, a woman cares their elders and offer clothes and other gifts to their in-laws and another needy person on the occasion of festivals like Deepawali, Holi, Makarskranti, etc. In India, a woman takes the utmost step of sacrificing her life for the conservation of biodiversity. In the year 1730 AD 363 Bishnois of Khejarli village lost their lives at the hands of soldiers of the princely state of Jodhpur (Rajasthan) as the Bishnois protested cutting of Prosopis cineraria tree by the soldiers (Who came to Khejarli to collect wood as ordered by the king of Jodhpur). Bishnois protested and start clinging to trees to save them and the soldiers started killing the Bishnois and the first one to sacrifice her life was a woman named Amrita Devi.

\section{Introduction}

Biodiversity means the varied life forms including different plants, animals and microorganisms present on the planet Earth. At present, the estimated numbers of living species reported from the world are 8.7 million (Mora et al., 2011). India's role is commendable in the contribution of biodiversity as it contributes about $7.8 \%$ the total life forms found in the world despite the fact that its geographical area is only $2.4 \%$ of the world (MoEF 2009). Biodiversity is crucial for the ecosystem and is the 
foundation of life on Earth as it provides us basic necessities of life i.e. food, shelter and clothing. Besides, it provides us with lifesupporting gas Oxygen, medicines, dyes, resins, stable climate and recreation. India is one of the mega-diversity nations of the world and she has a great diversity of natural ecosystems ranging from the cold and high Himalayan regions to the sea coasts; from the wet north-eastern green forests to the dry northwestern arid deserts; with different types of forests, wetlands, islands and the oceans (Sinha et al., 2010). India has fertile river basins of rivers like, Ganges, Brahmaputra and Indus. Here, we present paper is aimed to highlight the role of Indian Woman in the conservation of biodiversity. In India, women from all walks of life have contributed and are being contributed to the conservation of forests and wildlife.

\section{Materials and Methods}

The present study is based on an extensive literature search and the relevance of cultural practices observed by Indian women in general and tribal and rural women in particular which are very pertinent for the conservation of biodiversity. An Indian woman is considered as custodian of culture and biodiversity. Indian women, especially from tribes and rural areas, consider forests as a gift of mother nature to the mankind and a source of food, fodder, fuel wood, honey, resins, gums and other minor forest products for their livelihood (Awais et al., 2009). They are well versed with the economically important plant species of their area which they learn from their ancestors, make sustainable use of it and pass this knowledge to their future generations. This traditional knowledge helps them in collecting forest products. Tribal and rural women of India to nurture their families are actively involved in collection of seeds, grains, rhizomes, tubers and seedlings of varied types of cereals, vegetables, fruit trees, medicinal plants, spices, condiments, etc. from the forests and also to grow them on their piece of land which are repositories of local biodiversity of plants of utility near the human inhabitations of the tribal and rural areas of India (Rout et $a l ., 2010)$. This practice has not only played a significant role in domestication and conservation of varied plant species of Indian origins (Kaushik et al., 2018; Abhijeet et al., 2018; Rout et al., 2010; Gurulakshmi 2012; Srivastava and Adi Community 2009; Agarwal and Arora 1989; Gadgil, 1991).

An Indian woman is a custodian of culture and biodiversity. In India, it is a common practice of planting of 'Tulsi' (Ocimum sanctum), a traditionally proved medicinal herb in the courtyard of houses and the women worship and water it daily(Singh et al., 2012). This practice inculcates a feeling of love and devotion towards plants amongst the family members. While preparing meals in the morning in India woman prepares the first two chapattis for cow and dog which shows her strong bond of caring and conserving wildlife. In the morning she also offers a handful of food grains on her rooftops to birds along with an earthen bowl full of water to quench their thirst. She also spread a little of flour at ants' nest as their feed. She observes fast for the long life of her husband and sons on Karvachauth and Ahoi respectively on $4^{\text {th }}$ and $8^{\text {th }}$ day of Kartik, Hindi month each year. This is a unique tradition never heard in any other part of the world. Indian women do care for their elders and other needy people as they give clothes and other gifts on various Indian festivals. Indian women do care about a number of sacred plant and animal species by way of prayers which is a unique way of conserving biodiversity prevalent in India from the pre-Vedic period. Most important sacred plant of India is 'Peepal' (Ficus religiosa) which is found all over India in wild and is also planted in temples, village 
chaupals and along the roads as a shade tree. It is a robust and deciduous tree which usually reaches to a height of $10 \mathrm{~m}$ on which new leaves appear in April. It helps in purification of air as it releases plenty of Oxygen in the environment and an important Ayurvedic medicinal plant (Makhija et al., 2010). It has a dense canopy and bears an innumerable number of figs (fruits) in May-June. In India during May-June there is scanty vegetation; $F$. religiosa during this period supports a variety of frugivorous organisms including birds, rodents, squirrels, insects, etc. (Caughlin et al., 2012). It is also used for rearing of lac insects to produce 'shellack' and an important tree of Ayurvedic system of medicine. It is also a host of rare shrub, Loranthus. Other important sacred trees are $F$. bengalensis, Aegel marmelos, Cocos nucifera, Musa paradisiaca, Madhuca indica, Butea monosperma (Chandrakanth et al., 1990). The most important sacred animal species of India is a holy cow (Bos primigenius). It is especially revered to the Hindus (Frank 2000). Causing any harm to a cow is prohibited according to Hindu mythology.

\section{Results and Discussion}

\section{Amrita Devi (Rajasthan)}

She made history and become the first woman in the world to sacrifice her life to save 'Khejari' (Prosopis cineraria) a medium sized tree mainly grows in Rajasthan. Historically, King Abhay Singh of Jodhpur was constructing a new palace and he sent his soldiers to collect wood needed for a lime kiln. When the soldiers came to collect wood at Khejarli village, Bishnois protested and argued that cutting of green trees is a sin. The soldiers were determined to cut trees to collect wood. Amrita Devi embraced a tree, and asked them to axe her instead of cutting trees. The cruel soldiers axed Amrita Devi along with 362 other Bishnois on Tuesday $10^{\text {th }}$ day of the month of Bhadrapada according to Indian lunar calendar in 1730 AD (Jain 2011). This news spread like a wildfire is the adjoining areas including the king and he came to the spot, apologized to Bishnois and reprimanded his soldiers. He promised not to cut 'Khejari' tree from the region in future. Prosopis one of the sacred trees of India and Bishnois care it like their own children.

Scientifically it has been proved that this tree is of great importance to the ecology of India's desert ecosystem. It is an important source of forage to sheep, goats and camels (Bohra and Ghosh, 1980). It has the nitrogenfixing ability and it is a common observation that more the number of 'Khejari' trees in a field more is the production of 'Bajra' - pearl millet (Pennisetum typhoides), and it also supports good herbage growth under it (Saxena 1980). Ministry of Environment and Forests (MoEF) Government of India in honour of Amrita Devi founded 'Amrita Devi Bishnoi Wild Life Protection Award' from the year 2001 which is conferred each year on a dedicated person whose contribution is laudable in the field of conservation of biodiversity in India. Bishnoi also protects wild animals including blackbuck and chinkara. To this day, tradition is very much alive and Bishnois villages are refreshing scenes of greenery and plentiful wildlife in the Indian desert (Prakash and Ghosh 1980). Bishnoi women are known to breast-feed motherless fawns.

\section{Gaura Devi (Uttrakhand)}

Gaura Devi, an illiterate woman of Reni village of Chamoli district Uttrakhand is a proponent of 'Chipko Movement'. It was started in 1970 as a non-violent movement aimed at the protection and conservation of trees and forests being destroyed Misra and Tripathi 1978). On March 26, 1974, Gaura 
Devi and 27 women of the village stopped cutting of 1000 trees which were auctioned by the forest department to a contractor by hugging around the trees. This movement turned out to be a strong uprising against those who were destroying the natural resources of the forests and disturbing the whole ecological balance (Jain 1984). Later on, Environmentalists, like Sunder Lal Bahuguna and Chandi Prasad Bhatt spread this message to Himachal Pradesh, Uttar Pradesh, Haryana, Punjab and Delhi.

\section{Nagpanchami- Festival of Snakes Conservation}

It is only in India that even deadly poisonous cobras (Najanaja) are worshipped on the occasion of the festival, 'Nagpanchami' by Indians especially the women each year which falls on the fifth day after Amavasya (no moon day) of the Hindi month of Sharavana. On this day married women and the girls wake up early in the morning, take a head bath, arrange the things necessary for puja and start to reach a nearest Ant Hill(Snake's Home). Worship of snakes is to show their importance in the maintenance of the Ecosystem. It has been observed that rodents cause heavy damage to the food crops in the fields and as the snakes prey on them thus check their population naturally (Whitaker and Adani, 1983). Festival of Nagpanchami signifies the importance of conservation of biodiversity.

\section{'Vasantha Sena' (Green Force) - Periyar, Kerala (South India)}

This is a social organization, and all of its members are women, from the villages situated on the fringe of Periyar Tiger Reserve, Kerala who helps each other in their economic activities and also guards the sanctuary without getting any remuneration (Pillai and Suchintha, 2006). A small group of woman patrol every day from dawn to dusk in the forest voluntarily and due to it, illegal activities are checked.

\section{Suryamani Bhagat (Jharkhand's Jungle Girl)}

She is an activist with 'Save the Forests of Jharkhand Movement' and the founder of 'Torang' - tribal rights and cultural centre in Kotari village Ranchi of Jharkhand. She helps the tribals to have their due share from the forests and teaches them the importance of forests and asserts that 'Save Forests to save Ourselves'. Local children are very fond of her as she takes them to forests make them to learn names of the plants of medicinal importance and food trees and to conserve them. Her abilities of environmental awareness and importance of education to tribal people were recognized by UNICEF to portray her in its calendar of 2006.

\section{Koli-Agri Community (Maharashtra)}

'PithoriAma was' which falls on last day of 'sharvan' month (July) is a special occasion for womenfolk of Koli-Agri community as on this day married women without issue pray to goddess to fulfil their desire to have issues and on this occasion plants worshipped by them are: Adhatodavesica, Artemesia vulgaris, Bauhinia racemosa, Bombaxceiba, Cucurbita maxima, Curcuma aromatic, Cynodon dactylon, Ficus bengalensis, Gloriosa superb, Gmelina arborea and Moringa pterygosperma which are mentioned in Ayurveda to increase fertility (Tilwe, 2011).

\section{Vasuda Chakravathi, Rathika Ramasamy -} India's Women Wildlife Photographers

These are two brave and dedicated wildlife women photographers of India who are contributing to creating awareness for the 
conservation of wildlife with the help of their thrilling photographs. Vasudha from Banglore gave up her materialistic, conventional lifestyle in 2009 and made a 187-year-old cottage 'Hunting House' inside Kalhatti Hills (Nilgiri Jungle) as her home to know the flora and fauna of this South Indian biosphere reserves. She is the only woman photographers in India who has been living in the Jungles and capturing it on lens regularly. She is contributing to the collection of primary data of varied ranges of forests of the Nilgiri Hills. Rathika Ramasamy, another important wildlife photographer of India based in New Delhi, has taken thousands of unique wildlife photographs; regularly conducts wildlife photography workshops and thus helping to connect nature and human beings. It is pertinent to mention that wildlife photographs make common people aware of biodiversity and the need for its conservation (Dattari and Sreenivasan, 2011).

It is concluded that, biodiversity is the basis of life and anthropogenic activities are causing continuous harm to it. Rapid urbanization, population explosion and other developmental activities have resulted in shrinkage of forest area and habitat loss for wildlife. In the recent past, many plant and animal species have become extinct and many more species are endangered and near to extinction. If this trend continues it is possible that cereals like Rice and Wheat may become extinct, then what will we eat or if spices and condiments species are wiped out from the earth, then what will be the taste of our food? Therefore conservation of biodiversity is must for the continuance of life on the earth and the role of Indian women is of utmost importance for it. Indian women predominate as wild plant gatherers, home gardeners, plant domesticators and true custodian of biodiversity as discussed in this paper. There is a great need of involvements of Indian women in all programmes pertaining to environment and biodiversity conservation from the grassroots level to the highest level because they are blessed traditionally for the conservation of biodiversity. Beliefs and traditions have greater impact as compared to acts and Indian women are basically god fearing, passionate and caring for all living organisms, so they can play a supplementary role in all biodiversity conservation programmes initiated by Government.

\section{References}

Abhijeet, P. Kaushik and M. Verma. 2018. Sponge Gourd an Underexploited Cucurbit. Trends in Biosciences 11 (8): 1772-1774.

Agarwal, A. and D.R. Arora. 1989. "Women in Rural Society" Vohra Pub. \& Distributors Allahabad.

Awais, M., T. Alam and M Asif. 2009. Socioeconomic Empowerment of Tribal Women: An Indian Perspective. International Journal of Rural Studies 16(1): 1-11.

Bohra, M.C. and P.K. Ghosh. 1980. The nutritive value and digestibility of loong. In: Khejari in the Indian Desert. CAZRIICAR Pp. 45-47.

Caughlin, T.T., T. Ganesh and M.D. Lowman. 2012. Sacred fig trees promote frugivore visitation and tree seedling abundance in South India. Current Science 102(6): 918922.

Chandrakanth, M.G., J.K. Gilless, V. Gowramma and M.G. Nagaraja. 1990. Temple forests in India's forest development. Agroforestry Systems 11: 199-211.

Dattari, S. and R. Sreenivasan. 2011. Beyond the pretty pictures-Giving back to nature through Photography. Conservation India Dec. 13, 2011.

Frank, J.K. 2000. Holy Cow! The Apotheosis of Zebu, or Why the Cow is Sacred in Hinduism. Asian Folklore Studies 59(2): 181-203.

Gadgil, M. 1991. Conserving India's 
biodiversity: the social context. Evolutionary Trends in Plants 5: 3-8.

Gurulakshmi, K.G. 2012. Role of Women in Environmental Conservation. Zenith International Journal of Business Economics \& Management Reaserch2(4): 253-269.

Jain, P. 2011. Dharma and Ecology of Hindu Communities: Sustenance and Sustainability-The Bishnoi Community Heads lost Trees saved (Chapter 4, p5178) Ashgate Pp. 234.

Jain, S. 1984. Women and People's Ecologica Movement: A case study of Women's Role in Chipko Movement in Uttar Pradesh. Economic and Political Weekly 19(41): 1788-1794.

Kaushik, P., M.S. Dhaliwal and S. Kumar. Usefulness of Three under Exploited Vegetable Legumes-A Review. International Journal of Current Microbiology and Applied Sciences 7: 861-870.

Makhija, I.K., D.K. Sharma and D. Khamar. 2010. Phytochemistry and Pharmacological properties of Ficus religiosa: an overview. Annals of Biological Research 1(4): 171-180.

Misra, A. and S. Tripathi. 1978. Chipko Movement: Uttarakhand's bid to save forest wealth. People's Action.

MoEF-Government of India, New Delhi. 2009. India's Fourth National Report to the Convention on Biological Diversity. Pp. 156.

Mora, C., D.P. Tittensor, S. Adl, A.G.B. Simpson and B. Worm. 2011. How Many Species Are There on Earth and in the Ocean? PLoSBiol 9(8): 1-8.

Pillai K.R. and B. Suchintha. 2006. Women empowerment for biodiversity conservation: a case from Periyar Tiger Reserve, Kerala, India. International Journal of Agricultural Resources, Governance and Ecology 5(4): 338-355.

Prakash, I and P.K. Ghosh. 1980. HumanAnimal interactions in the Rajasthan Desert. Journal of Bombay Natural History society75(Suppl): 1259-61.

Rout, S.D., S.K. Panda, N. Mishra and T. Panda. 2010. Role of Tribals in collection of commercial non-timber forest products in Mayurbhanj District Orissa. Stud Tribes Tribals 8(1): 21-25.

Saxena, S.K. 1980. Herbage growth under khejari canopy. In: Khejri in the Indian desert. CAZRI-ICAR Pp. 49, 25-27, 64-67.

Singh, E., S. Sharma, J. Dwivedi and S. Sharma. 2012. Diversified potential of Oscimum sanctum Linn. (Tulsi): An Exhaustive Survey. Journal of Natural Product and Plant Resources. 2(1): 39-48.

Sinha, R.K., M. Dube, R.D. Tripathi, A. Kumar, P. Tripathi and S. Dwivedi. 2010. India a Megadiversity Nation. International Society of Environmental Botanists, Environews. 16 (4). Oct.

Srivastava, R.C. and Adi Community. 2009. Traditional knowledge of Aditribe of Arunachal Pradesh on Plants. Indian Journal of Traditional Knowledge 8(2): 146-153.

Tilwe, D. 2011. Biodiversity of India - A wiki Resource of Indian Biodiversity.

Whitaker, R. and R. Adani. 1983. Preliminary field study on snakes as agents of management of rodent populations. Indian Forester 109: 417-419.

\section{How to cite this article:}

Ishan Saini, Prashant Kaushik and Babu Lal Saini. 2019. Role of Indian Women in Conservation of Biodiversity. Int.J.Curr.Microbiol.App.Sci. 8(04): 63-68.

doi: https://doi.org/10.20546/ijcmas.2019.804.008 